\title{
Community-Level Gender Equity and Extramarital Sexual Risk-Taking Among Married Men in Eight African Countries
}

By Rob

Stephenson

Rob Stephenson is assistant professor, Hubert Department of Global Health, Rollins

School of Public

Health, Emory University, Atlanta, GA, USA.
CONTEXT: In many parts of Africa, women are most likely to become infected with HIV by having unprotected sex with their husbands, who may have acquired the virus through extramarital sex. However, the ways in which aspects of community environments - particularly those related to gender equity-shape men's extramarital sexual risk-taking are not well understood.

METHODS: Demographic and Health Survey data from eight African countries (Chad, Ghana, Malawi, Nigeria, Tanzania, Uganda, Zambia and Zimbabwe) were used to examine associations between married men's engaging in risky extramarital sex (i.e., having had both unprotected sex and extramarital sex) and indicators of gender equity and other community characteristics. Separate multilevel logistic regression models that incorporated individual, household and community measures were created for each country.

RESULTS: In five countries, men who lived in communities with more equal ratios of women to men with at least a primary education were less likely to report risky extramarital sexual activity (odds ratios, 0.4-0.6). A similar relationship was found in four countries for the ratio of women to men who were employed (0.4-0.5). In three countries, men who lived in communities with more conservative attitudes toward wife-beating or male decision making had elevated odds of extramarital sexual risk-taking (1.1-1.5).

CONCLUSIONS: While HIV prevention programs should focus on reducing gender inequities, they also need to recognize the conservative cultural factors that influence the formation of men's masculine identities and, in turn, affect their sexual behavior.

International Perspectives on Sexual and Reproductive Health, 2010,36(4):178-188
A substantial body of evidence suggests that for many women in Africa, the greatest risk of HIV infection lies in marriage, and the greatest source of HIV infection is unprotected sex with their husbands. ${ }^{1-4}$ Recent estimates suggest that nearly $80 \%$ of new HIV infections among heterosexual urban residents in Africa occur within marital or cohabiting unions. ${ }^{2}$ In such cases, one partner either is HIV-positive prior to union formation or has acquired the virus through extramarital sexual activity. A pronounced double standard regarding extramarital sexual behavior exists in much of Africa; married men are much more likely than married women to engage in extramarital sex, and among males such activity is often socially and culturally condoned..$^{5-7}$ Therefore, African men commonly have concurrent marital (regular) and extramarital (casual) sex partners. In fact, although they have roughly the same number of partners as their American and European counterparts, they are more likely than Americans and Europeans to have concurrent rather than serial relationships. ${ }^{8-10}$ Some investigators have argued that this pattern of concurrency has played an important part in driving the HIV epidemic in Africa. ${ }^{11}$

Despite the high prevalence of extramarital sexuality in the region, levels of condom use are low, particularly with regular partners. Men often report that condoms are un- necessary within unions and should be used only with casual partners. ${ }^{12-14}$ In addition, some evidence indicates that men use condoms inconsistently with casual partners. ${ }^{14-16}$ Thus, women are susceptible to HIV infection within marriage through unprotected sex with their husband if he has had extramarital exposure to the virus. While some previous studies have examined the factors associated with high-risk sexual behavior among African men, few have considered how such behavior is shaped by a man's social, cultural and economic environment. This analysis is designed to examine associations between African men's reports of risky extramarital sex and the economic, demographic and behavioral characteristics of residents of the communities in which they live-and more specifically, to identify how community-level gender equity, as measured by access to social capital, shapes married men's engagement in risky extramarital sex.

\section{BACKGROUND}

Barker and Ricardo have noted that in many cases, discourse around gender in resource-poor contexts refers almost exclusively to the disadvantages that women and girls face in obtaining good health outcomes and access to social capital (e.g., education). ${ }^{16}$ Such a focus is to some degree warranted, given the extent of gender inequities in 
health (and HIV infection in particular) in much of SubSaharan Africa. However, the combination of gender inequities in social power (which are often culturally and socially ingrained) and the high levels of sexual risk-taking among men point to the potential for men to play a key role in limiting the HIV epidemic in Africa. ${ }^{16}$ Additionally, many HIV prevention messages have focused on promoting monogamy within marital or cohabiting unions. ${ }^{17}$ The success of such programmatic efforts is often limited, however, in environments where men's extramarital sexual activities are not only socially condoned but are a defining element of masculine identity, and where condom use within unions is considered unacceptable. Therefore, to design intervention efforts that recognize the realities of relationships and sexual behaviors-and that by doing so, shift the focus toward the roles and responsibilities of men-one must understand how extramarital sexual behavior is socially and culturally constructed.

Levels of concurrent sexual partnering are high in many African countries, and men are more likely than women to report having extramarital partners. ${ }^{18}$ Men in polygamous unions are less likely than those in monogamous ones to engage in extramarital sex, ${ }^{19-21}$ perhaps because of their ability to change partners within marriage. ${ }^{19}$ The double standard in many African countries between men's and women's engagement in extramarital sex is to some degree a product of social and cultural conditioning, which often emphasizes male domination in relationships, espouses traditional ideals of virginity and fidelity for women and links men's social status to their sexual activity. Although no single definition of masculinity defines all African men, studies have highlighted the types of masculine identities that are believed to encourage extramarital sexual activity. ${ }^{9}$ For example, Hunter has noted that the establishment of financial independence and a family are fundamental elements of African masculine identity, and that for many young men sexual experience is associated with initiation into adulthood and attainment of socially recognized manhood. ${ }^{9}$

Moreover, traditional ideals of masculinity often depict male sexual needs as uncontrollable, having multiple partners as evidence of sexual prowess, and dominance over women as natural. ${ }^{22}$ In contrast, women are expected to be financially dependent on and faithful to their husbands. ${ }^{5,6,9}$ Thus, young men often have disproportionate power in intimate relationships with women. ${ }^{8}$ The consequences of such inequity include men's perpetration of violence toward women, lack of condom use within unions and participation in extramarital sex as a sign of social status and prowess. ${ }^{23-25}$ In fact, young women are often socialized to tolerate and accept infidelity and violence. ${ }^{26}$ Rates of intimate partner violence are elevated among men who report having multiple sex partners, suggesting a linkage between norms of male entitlement to sex and dominance within relationships. ${ }^{27}$ In such circumstances, women are particularly vulnerable to HIV infection, because they lack the power to negotiate condom use.
Previous work has suggested that in many parts of Africa, young men's sexual activities are often an attempt to display sexual competence or achievement to peers, rather than acts of intimacy. ${ }^{28,29}$ In one study, a significant minority of young men in South Africa reported feeling obliged to have sex before marriage for fear of social rejection. ${ }^{30}$ This pattern of using sexual behavior as a means to peer acceptance often continues into adulthood, and leads to extramarital sexual activity. ${ }^{31}$ Thus, extramarital relationships are often as much about masculinity or social class as about sex itself. In other cases, men engage in extramarital sex simply to meet sexual desires. Men are more likely to have extramarital sex during their wives' period of postpartum abstinence, and this sex is likely to be unprotected. ${ }^{32,33}$ Additionally, men have more opportunities than women to participate in wage labor and temporary migration, which provide motivation and opportunity for extramarital partnerships. ${ }^{34-37}$

Regardless of a man's motive for extramarital sexual activity, concurrent partnerships clearly increase his risk of HIV infection. Other factors contribute to this increased risk. Rivers and Aggleton have noted that many men lack knowledge about the sexual transmission of HIV, which may put them-and their regular partner-at risk for infection. ${ }^{22}$ Others have found that many men rely on appearance or misconceptions to determine whether a potential partner is infected with HIV, and thus often do not use condoms, even with casual partners. ${ }^{14,15}$ Within unions, men and women frequently view condom use as a sign of unfaithfulness or lack of trust. ${ }^{12-14}$ A study in South Africa found that young women identified their ideal relationship as one in which the man makes the sexual decisions, including those concerning use of condoms. ${ }^{12}$

In addition, recent work has documented a relationship between poverty and extramarital sexual behavior. Silberschmidt has argued that when levels of unemployment are high, extramarital sexual activity boosts men's self-esteem and perception of their own social standing. ${ }^{38}$ Because an unemployed man is unable to fulfill traditional economic masculine roles, his sense of social recognition and manhood may be diminished, ${ }^{39,40}$ and he may engage in extramarital sex as a means of fulfilling some expectations of male behavior. Poverty may also increase a woman's tolerance of infidelity; if she discovers that her husband is engaging in extramarital sexual activity, her economic dependence on him may prevent her from challenging his behavior or negotiating condom use. ${ }^{8}$ In addition, women who lack economic alternatives may become casual partners of married men and engage in transactional sex; in these relationships, the power for decisions about condom use often lies with the male.

Although sufficient evidence exists concerning the high levels of concurrent sexual partnering in many parts of Africa and the vulnerability of married women to HIV infection, few studies have examined the community factors associated with men's extramarital sexual behavior. The current study explored this issue by examining how the 
TABLE 1. Percentage distribution of married or cohabiting sexually active men in Sub-Saharan Africa, by selected characteristics, according to country

\begin{tabular}{|c|c|c|c|c|c|c|c|c|}
\hline Characteristic & $\begin{array}{l}\text { Chad } \\
(\mathrm{N}=1,062)\end{array}$ & $\begin{array}{l}\text { Ghana } \\
(\mathrm{N}=1,821)\end{array}$ & $\begin{array}{l}\text { Malawi } \\
(\mathrm{N}=2,114)\end{array}$ & $\begin{array}{l}\text { Nigeria } \\
(\mathrm{N}=1,196)\end{array}$ & $\begin{array}{l}\text { Tanzania } \\
(\mathrm{N}=1,379)\end{array}$ & $\begin{array}{l}\text { Uganda } \\
(\mathrm{N}=1,443)\end{array}$ & $\begin{array}{l}\text { Zambia } \\
(\mathrm{N}=780)\end{array}$ & $\begin{array}{l}\text { Zimbabwe } \\
(\mathrm{N}=3,367)\end{array}$ \\
\hline \multicolumn{9}{|l|}{ INDIVIDUAL } \\
\hline \multicolumn{9}{|l|}{ Age } \\
\hline $15-24$ & 7.5 & 4.9 & 13.6 & 8.0 & 10.0 & 11.1 & 14.3 & 9.3 \\
\hline $25-29$ & 17.4 & 11.2 & 23.5 & 10.2 & 19.6 & 16.9 & 14.3 & 19.6 \\
\hline $30-34$ & 16.9 & 17.9 & 20.6 & 14.5 & 22.5 & 22.0 & 15.2 & 22.4 \\
\hline $35-39$ & 15.9 & 15.5 & 12.9 & 12.0 & 18.5 & 19.2 & 12.2 & 16.7 \\
\hline$\geq 40$ & 42.1 & 50.4 & 29.4 & 55.3 & 29.4 & 30.8 & 44.0 & 32.1 \\
\hline \multicolumn{9}{|l|}{ Union type } \\
\hline Married & 88.6 & 96.4 & 95.4 & 94.2 & 95.5 & 90.2 & 97.3 & 94.4 \\
\hline Cohabiting & 11.4 & 3.6 & 4.6 & 5.8 & 4.5 & 9.8 & 2.7 & 5.6 \\
\hline \multicolumn{9}{|l|}{ Residence } \\
\hline Rural & 51.4 & 63.6 & 87.3 & 67.4 & 80.6 & 87.3 & 72.8 & 65.3 \\
\hline Urban & 48.6 & 36.8 & 12.7 & 32.6 & 19.4 & 12.7 & 27.2 & 34.7 \\
\hline \multicolumn{9}{|l|}{ Age at first sex } \\
\hline$\leq 15$ & 14.9 & 8.7 & 23.3 & 8.8 & 18.5 & 22.5 & 32.6 & 8.9 \\
\hline $16-20$ & 44.1 & 29.9 & 50.9 & 45.6 & 51.6 & 61.9 & 44.7 & 54.6 \\
\hline$\geq 21$ & 41.0 & 61.5 & 25.8 & 45.6 & 29.9 & 15.7 & 22.7 & 36.5 \\
\hline \multicolumn{9}{|l|}{ Education } \\
\hline None & 51.6 & 32.5 & 14.5 & 31.9 & 4.9 & 8.0 & 6.1 & 2.6 \\
\hline Primary & 23.5 & 30.0 & 64.8 & 13.4 & 73.0 & 66.3 & 22.1 & 32.3 \\
\hline Secondary & 19.1 & 25.3 & 18.8 & 46.3 & 8.4 & 19.2 & 31.3 & 57.6 \\
\hline >secondary & 5.8 & 12.2 & 1.9 & 8.5 & 3.6 & 6.5 & 7.4 & 7.5 \\
\hline \multicolumn{9}{|l|}{ Employed } \\
\hline Yes & 93.3 & 94.4 & 71.1 & 97.3 & 98.2 & 98.9 & 85.0 & 81.1 \\
\hline No & 6.7 & 5.6 & 28.9 & 2.7 & 1.8 & 1.1 & 15.0 & 18.9 \\
\hline \multicolumn{9}{|l|}{ HOUSEHOLD } \\
\hline \multicolumn{9}{|l|}{ Wealth quintile } \\
\hline Lowest & 14.8 & 21.2 & 13.4 & 26.6 & 19.6 & 21.1 & $\mathrm{u}$ & 18.9 \\
\hline Second lowest & 14.3 & 20.2 & 21.6 & 20.8 & 21.3 & 21.8 & $\mathrm{u}$ & 19.6 \\
\hline Middle & 11.8 & 19.2 & 25.4 & 18.7 & 19.1 & 18.8 & $\mathrm{u}$ & 14.4 \\
\hline Second highest & 16.7 & 18.6 & 22.9 & 14.6 & 21.8 & 18.4 & $\mathrm{u}$ & 27.4 \\
\hline Highest & 42.9 & 21.0 & 16.4 & 19.4 & 18.4 & 19.8 & $\mathrm{u}$ & 19.6 \\
\hline Total & 100.0 & 100.0 & 100.0 & 100.0 & 100.0 & 100.0 & 100.0 & 100.0 \\
\hline
\end{tabular}

community dimensions of gender equity, economics, behavior and demographic characteristics are associated with participation in high-risk extramarital sexual activity.

\section{METHODS}

Data

Data for this analysis are taken from Demographic and Health Surveys (DHS) conducted in eight African countries: Chad (2004), Ghana (2003), Malawi (2004), Nigeria (2003), Tanzania (2004-2005), Uganda (2006), Zambia (2001-2002) and Zimbabwe (2005-2006). These countries were chosen from a list of African countries in which a DHS that included a module on HIV/AIDS and sexual behavior had been conducted during the past 10 years. Countries on the list were stratified by HIV prevalence $(<5 \%, 5-10 \%$ or $>10 \%)$, and study countries were selected from each of these categories to include those with a range of social and economic characteristics and to reflect the researcher's experience in working with these data sets and conducting research in these countries.

Each DHS collects data on fertility, family planning and maternal health among women aged 15-49, together with information on the demographic, social and economic characteristics of the women and members of their household. The surveys also examine attitudes toward gender roles, exposure to health care messages in the media and knowledge of and attitudes toward the use of reproductive health services. In each of the study countries, a companion survey of males was also conducted. The age range of male participants varied; in Chad, Ghana, Nigeria and Zambia, the sample consisted of men aged 15-59, but the range was 15-49 in Tanzania and 15-54 in Malawi, Uganda and Zimbabwe. The men's questionnaires collected much of the same information as the women's, but were shorter because they did not include a reproductive history or questions on maternal and child health. However, they did include a module on HIV/AIDS and sexual behavior that was standardized across countries.

To obtain nationally representative samples, the DHS uses separate stratified, multistage cluster sample designs for rural and urban areas. The rate of nonresponse for men in the eight countries was 3-5\%; the number of men sur- 
veyed ranged from 1,887 in Chad to 7,175 in Zimbabwe. * To identify factors associated with high-risk marital and extramarital sex, the analytic samples were restricted to married or cohabiting, sexually active men; sample sizes ranged from 780 in Zambia to 3,367 in Zimbabwe ${ }^{\dagger}$

\section{Dependent Variable}

The DHS collects data on the number of sexual partners the respondent had had in the 12 months prior to the survey, his or her type of relationship with each partner and whether condoms were used at last sex with each partner. The dependent variable for this analysis is a binary variable that captures whether the respondent had recently engaged in high-risk marital and extramarital sexual activity. The variable was coded 1 if the respondent reported having had one or more extramarital sex partners and not having used a condom at last sex with his regular partner, his casual partners or both. Given the analysis' focus on concurrent risky sexual partnerships, and that condom use with regular partners was low (particularly among those who reported no casual partners), respondents who reported having had no casual partners were combined into one risk group, regardless of whether they had used a condom at last sex. Thus, a respondent was given a score of 0 if he reported having had sex only with his regular partner.

\section{Analytic Approach and Covariates}

Each DHS data set has a hierarchical structure, violating the assumption of independence of ordinary logistic regression models. Therefore, this analysis employed a multilevel modeling technique to account for the hierarchical structure of the data and to facilitate estimation of communitylevel (i.e., primary sampling unit-level) influences on risky sexual behavior. The multilevel modeling strategy also corrects the estimated standard errors to allow for clustering of observations within units. ${ }^{41}$ Multilevel models allow the identification of clustering in risky sexual behavior (also known as the random effect), providing a measure of the extent to which the odds of reporting risky sexual behavior vary among communities. Separate multilevel logistic models were fitted for males in each of the eight countries using the STATA software package, version 11.

Given the paucity of studies that have examined how communities shape men's engaging in risky extramarital sex, the current analysis adopted an exploratory approach. Three levels of potential influence on risky sexual behavior were considered: individual, household and community. The choice of individual and household covariates was informed by previous studies on the factors associated with sexual risk-taking in these contexts, although not necessarily among married men. Bivariate analyses were performed to examine the reporting of risky extramarital sex according to individual and household factors, including age, educational attainment, ethnicity, religion, marital status, age at sexual debut, employment, occupation, access to media, knowledge of HIV transmission,
FIGURE 1. Percentage of married or cohabiting sexually active men in Sub-Saharan Africa who had had risky extramarital sex in the past 12 months, by country

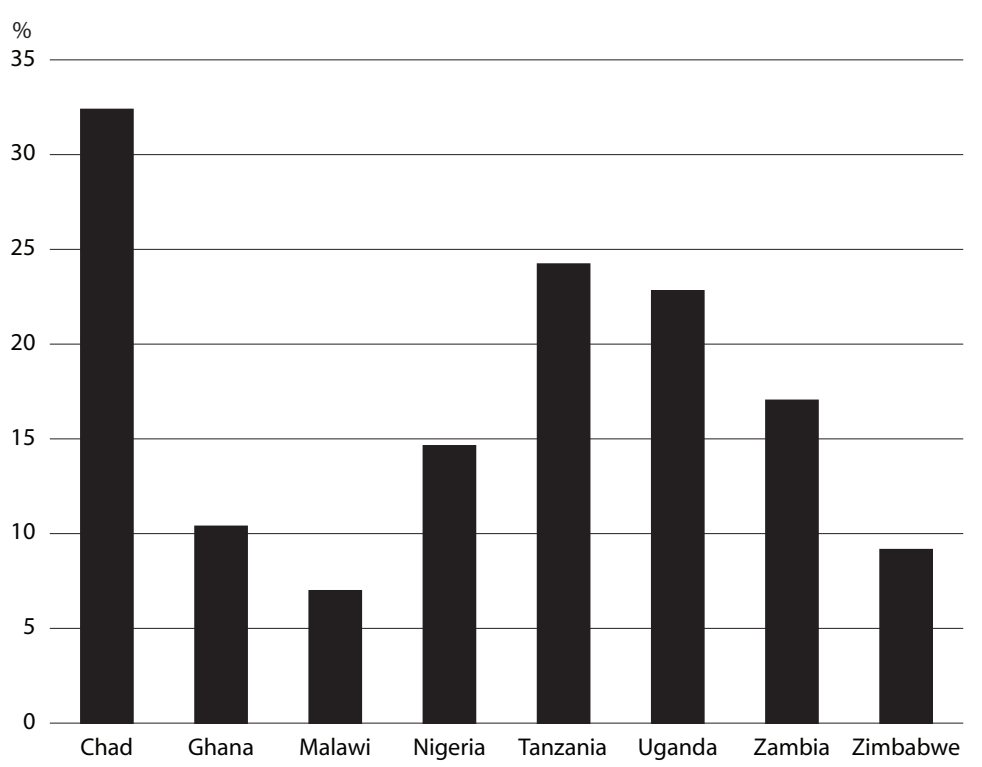

time spent away from home and household wealth. These variables were selected for the multivariate analysis if they were associated with risky sex at the $\mathrm{p}<.05$ level in at least one country. Six individual-level variables and one household-level variable were included in the final models (Table 1).

In the absence of a community survey, community-level data were derived from individual responses. This involved aggregating individual data to the primary sampling unit (minus the index response) to form proxy community measures. Because men's sexual behavior was conceptualized as influenced by the aggregate behaviors and characteristics of both men and women in their community, the community-level variables were created using data from both the men's and women's surveys. (The women's data were linked to the men's via the primary sampling unit identifier).

The selection of the community-level variables was informed by the literature on factors that shape the extramarital sexual behavior of African men, and variables that had significant bivariate relationships with the reporting of risky sex at the $\mathrm{p}<.05$ level were included in the multivariate models. The community variables were conceptualized into three categories:

- Community economics. Studies have demonstrated that men's participation in extramarital sex may be a mechanism for enacting traditional masculinities that prescribe greater autonomy to men and foster women's financial and social dependence on them. ${ }^{28,29}$ This dependence is to

*The full DHS male sample sizes for the other six countries are as follows: Ghana, 5,015; Malawi, 3,261;Nigeria, 2,346; Tanzania, 2,635;Uganda,2,503; and Zambia, 2,145.

†The analytic sample sizes for the other six countries are as follows: Chad, 1,062; Ghana, 1,821; Malawi, 2,114; Nigeria, 1,196; Tanzania, 1,379; and Uganda, 1,443. 
some extent created by the lack of opportunities for women to accrue social capital in the form of education and employment. ${ }^{2,9,16}$ If a man resides in a community where economic and educational opportunities for women are similar to those of men, so that women's dependence on men is reduced, his participation in extramarital sexual activity may be reduced as well. To examine this possibility, the analysis used two community-level variables: the ratio of employed women to employed men, and the ratio of women to men who have at least a primary education.

- Community behavior and knowledge. Because men's extramarital sexual behavior is often socially condoned-the result of the double standard that encourages men to engage in extramarital sex to prove their masculinity ${ }^{9,18}$-men who live in communities with more conservative gender norms may be more likely to have risky extramarital sex. To examine this possibility, the analysis uses measures of men's views on the acceptability of wife-beating and of household decision making. For each measure, an index was created at the individual level, and then aggregated to the primary sampling unit. The index of attitudes toward wife-beating comprised five variables, each of which assessed the acceptability of wife-beating under a specific cir- cumstance (if the wife were to leave home without permission, neglect the children, burn food, argue with her husband or refuse to have sex). Men who scored 5 on this index approved of wife-beating under each of these circumstances. The index of decision making was created from five variables that measured men's roles in certain decisions (purchasing large goods, purchasing small daily goods, visiting family or relatives, choosing food to be cooked and determining how money earned is spent); men who scored 5 on this index reported that they had the final say in each of these decisions. Data on attitudes toward wife-beating and decision making were not available for Chad.

- Demographic characteristics. Women who live in communities where early marriage and fertility are expected may have fewer opportunities to accrue social capital because of the opportunity costs of marriage and childbearing. Early ages at marriage and childbearing may also reflect conservative attitudes within a society toward the roles of women. Men living in these communities may be more likely than those in other communities to participate in risky extramarital sex, because they have higher levels of economic and social freedom, and because prevailing

\begin{tabular}{|c|c|c|c|c|c|c|c|c|}
\hline Characteristic & $\begin{array}{l}\text { Chad } \\
(\mathrm{N}=1,062)\end{array}$ & $\begin{array}{l}\text { Ghana } \\
(\mathrm{N}=1,821)\end{array}$ & $\begin{array}{l}\text { Malawi } \\
(\mathrm{N}=2,114)\end{array}$ & $\begin{array}{l}\text { Nigeria } \\
(\mathrm{N}=1,196)\end{array}$ & $\begin{array}{l}\text { Tanzania } \\
(\mathrm{N}=1,379)\end{array}$ & $\begin{array}{l}\text { Uganda } \\
(\mathrm{N}=1,443)\end{array}$ & $\begin{array}{l}\text { Zambia } \\
(\mathrm{N}=780)\end{array}$ & $\begin{array}{c}\text { Zimbabwe } \\
(\mathrm{N}=3,367)\end{array}$ \\
\hline \multicolumn{9}{|l|}{ INDIVIDUAL } \\
\hline \multicolumn{9}{|l|}{ Age } \\
\hline $15-24$ & $13.9^{*}$ & 5.0 & 6.9 & $9.5^{*}$ & 12.8 & 6.9 & 11.7 & 3.2 \\
\hline $25-29$ & 18.8 & 5.3 & 5.3 & 8.1 & 13.8 & 7.6 & 11.3 & 3.1 \\
\hline $30-34$ & 12.2 & 7.9 & 6.9 & 13.9 & 12.1 & 7.9 & 9.6 & 2.4 \\
\hline $35-39$ & 20.2 & 8.9 & 9.9 & 13.8 & 8.6 & 6.2 & 6.6 & 1.9 \\
\hline$\geq 40$ & 23.4 & 9.4 & 10.3 & 12.7 & 10.2 & 10.6 & 6.4 & 2.3 \\
\hline \multicolumn{9}{|l|}{ Union type } \\
\hline Married & $15.7^{* * *}$ & $7.9^{*}$ & $6.7^{* *}$ & 11.8 & $10.8^{* *}$ & 7.2 & 9.6 & $1.4^{*}$ \\
\hline Cohabiting & 17.6 & 4.5 & 11.9 & 10.1 & 16.3 & 8.2 & 10.0 & 3.1 \\
\hline \multicolumn{9}{|l|}{ Residence } \\
\hline Rural & $13.7^{*}$ & 8.6 & 4.7 & $14.4^{* *}$ & $12.2^{* *}$ & $8.0^{*}$ & $10.2^{*}$ & 2.4 \\
\hline Urban & 18.9 & 6.6 & 4.1 & 7.6 & 5.0 & 4.0 & 8.4 & 1.9 \\
\hline \multicolumn{9}{|l|}{ Age at first sex } \\
\hline$\leq 15$ & $13.6^{*}$ & $9.3^{*}$ & $9.5^{*}$ & $14.4^{*}$ & $14.2^{* *}$ & $8.9^{*}$ & $13.2^{* *}$ & $4.5^{*}$ \\
\hline $16-20$ & 16.6 & 8.1 & 7.6 & 11.5 & 11.2 & 7.2 & 7.6 & 2.6 \\
\hline$\geq 21$ & 11.6 & 6.7 & 6.6 & 10.6 & 4.2 & 4.6 & 5.4 & 1.4 \\
\hline \multicolumn{9}{|l|}{ Education } \\
\hline None & $21.8^{*}$ & $10.4^{*}$ & $5.9^{* *}$ & $13.9^{*}$ & $13.1^{*}$ & $5.0^{*}$ & $13.1^{*}$ & $4.2^{*}$ \\
\hline Primary & 14.2 & 8.9 & 8.9 & 11.2 & 11.4 & 5.4 & 11.5 & 3.5 \\
\hline Secondary & 9.5 & 6.6 & 4.4 & 10.8 & 2.5 & 4.3 & 7.4 & 2.1 \\
\hline >secondary & 7.7 & 5.7 & 0.8 & 9.7 & 4.4 & 1.4 & 3.2 & 1.2 \\
\hline \multicolumn{9}{|l|}{ Employed } \\
\hline Yes & $16.9^{* *}$ & $8.5^{*}$ & 6.9 & 11.2 & $10.8^{*}$ & $7.0^{* *}$ & $10.0^{*}$ & 2.4 \\
\hline No & 11.1 & 4.3 & 7.7 & 12.6 & 7.2 & 2.1 & 8.7 & 2.7 \\
\hline \multicolumn{9}{|l|}{$\begin{array}{l}\text { HOUSEHOLD } \\
\text { Wealth quintile }\end{array}$} \\
\hline Lowest & 7.8 & 3.9 & 4.1 & $12.9^{*}$ & $14.9^{*}$ & $8.9^{*}$ & $\mathrm{u}$ & $4.3^{*}$ \\
\hline Second lowest & 9.1 & 3.9 & 4.9 & 9.1 & 12.7 & 7.9 & u & 2.3 \\
\hline Middle & 12.1 & 5.1 & 4.0 & 9.3 & 12.7 & 8.5 & $\mathrm{u}$ & 2.2 \\
\hline Second highest & 9.6 & 5.5 & 4.6 & 6.8 & 8.5 & 7.2 & u & 2.6 \\
\hline Highest & 10.4 & 3.9 & 3.0 & 5.4 & 4.8 & 4.9 & u & 0.9 \\
\hline
\end{tabular}




\begin{tabular}{|c|c|c|c|c|c|c|c|c|}
\hline Characteristic & Chad & Ghana & Malawi & Nigeria & Tanzania & Uganda & Zambia & Zimbabwe \\
\hline $\begin{array}{l}\text { ECONOMIC } \\
\text { Ratio of women to } \\
\text { men employed }\end{array}$ & $0.75(0.00-1.53)$ & $0.77(0.00-2.62)$ & $0.21(0.00-2.78)$ & $0.96(0.33-2.50)$ & $0.90(0.12-2.23)$ & $0.82(0.35-1.50)$ & $0.89(0.00-3.00)$ & $0.58(0.00-2.12)$ \\
\hline $\begin{array}{l}\text { Ratio of women to } \\
\text { men with } \geq \text { primary } \\
\text { education }\end{array}$ & $0.53(0.00-1.62)$ & $0.67(0.00-1.55)$ & $0.86(0.90-2.07)$ & $0.80(0.00-2.33)$ & $0.86(0.00-2.47)$ & $0.81(0.14-1.69)$ & $0.91(0.35-2.68)$ & $0.97(0.61-1.35)$ \\
\hline $\begin{array}{l}\text { BEHAVIOR AND KNOV } \\
\text { Men's attitudes } \\
\text { toward wife } \\
\text { beatingt }\end{array}$ & $\begin{array}{l}\text { WLEDGE } \\
\mathrm{u}\end{array}$ & $1.85(0.00-3.16)$ & $1.35(0.00-2.14)$ & $1.43(0.00-2.66)$ & $0.98(0.00-4.52)$ & $1.54(0.00-4.50)$ & $1.06(0.00-3.00)$ & $1.72(0.00-2.41)$ \\
\hline $\begin{array}{l}\text { Men's attitudes } \\
\text { toward decision } \\
\text { making } †\end{array}$ & u & $1.13(0.00-4.00)$ & $1.30(0.00-2.90)$ & $1.80(0.00-4.00)$ & $0.98(0.00-3.00)$ & $0.74(0.00-2.66)$ & $1.98(0.00-5.00)$ & $0.45(0.00-1.53)$ \\
\hline $\begin{array}{l}\text { Women's age at } \\
\text { first childbirth }\end{array}$ & $\begin{array}{l}17.90 \\
(15.35-21.13)\end{array}$ & $\begin{array}{l}18.69 \\
(15.00-26.00)\end{array}$ & $\begin{array}{l}18.35 \\
(15.44-21.77)\end{array}$ & $\begin{array}{l}19.73 \\
(16.11-24.33)\end{array}$ & $\begin{array}{l}18.41 \\
(16.37-23.15)\end{array}$ & $\begin{array}{l}18.22 \\
(15.83-23.00)\end{array}$ & $\begin{array}{l}18.18 \\
(16.22-21.83)\end{array}$ & $\begin{array}{l}19.20 \\
(16.26-24.75)\end{array}$ \\
\hline
\end{tabular}

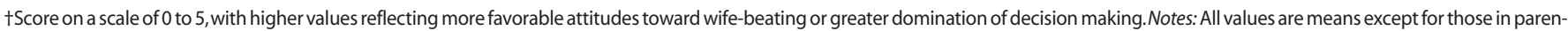
theses, which are ranges. $u=$ unavailable.

attitudes prescribe more autonomy to men than to women. Therefore, the analysis included women's mean age at marriage and mean age at first childbirth.

\section{RESULTS}

The men included in this analysis were largely from rural areas, were employed for pay, were married and had first had sex after the age of 15 (Table 1). Men's educational and household wealth profiles varied by country, reflecting country-specific levels of literacy and poverty. The proportion of men reporting recent risky extramarital sex varied considerably across countries, ranging from $7 \%$ in Malawi to 33\% in Chad (Figure 1, page 181).

In bivariate analyses, the proportion of men who had had risky extramarital sex differed in all eight countries according to educational attainment and age at first sex (Table 2). In addition, the proportion differed by union type, place of residence, employment status and household wealth in four or more countries.

The community-level measures revealed wide variation among countries (Table 3). For example, the ratio of employed women to employed men ranged from 0.21 in Malawi to 0.96 in Nigeria, and women's age at marriage ranged from 15.9 in Chad to 18.8 in Nigeria. In bivariate analyses, the two community-level measures of social capital (gender ratios for employment and education) were associated with risky extramarital sex in 4-5 countries, but the other community variables were related to risky sex in only one or two countries (Table 4, page 184).

In the multilevel analysis, the relationship between age and sexual risk-taking was inconsistent across countries (Table 5, page 185). While extramarital risky sex was generally not associated with age, the odds of this behavior were elevated among the four oldest age-groups in Nigeria (odds ratios, 1.8-2.7) and among men aged 25-29 in Zimbabwe (1.4). In Chad, men 40 or older had significantly lower odds of reporting risky sex than did men 24 or younger (0.6). Cohabiting men in Chad, Ghana, Malawi and Zimbabwe were less likely than married men in those countries to have engaged in risky sex (0.1-0.6); only in Uganda was cohabitation associated with increased sexual risk-taking relative to married men (1.6). Compared with men who lived in urban areas, rural residents in Chad were less likely to report sexual risk-taking (0.6) but those in Zambia were more likely to do so (1.5). In all eight countries, men who reported being 21 or older at first sex were less likely than men who had had their sexual debut before age 16 to have engaged in extramarital sexual risk-taking (0.4-0.7).

Few significant relationships emerged between educational attainment and extramarital sexual risk-taking; relative to men with no education, those in Malawi, Tanzania and Uganda who had a primary education had higher odds of participating in risky extramarital sex (1.4-1.8). In six of the study countries, men who worked for pay had elevated odds of reporting sexual risk-taking (1.3-2.1). Household wealth was associated with sexual risk-taking in only two instances: In Nigeria, men in the wealthiest households had significantly lower odds of reporting risky sex than did men in the poorest households (0.6), while in Uganda men in the wealthiest households had elevated odds of reporting risky sex (1.5).

Living in a community in which there was a more equal ratio of employed women to employed men was associated with decreased odds of reporting risky extramarital sex for men in Chad, Nigeria, Tanzania and Zimbabwe (odds ratios, $0.4-0.5$ per 0.10 increase in the ratio). Similarly, residence in a community with a more equal ratio of women 


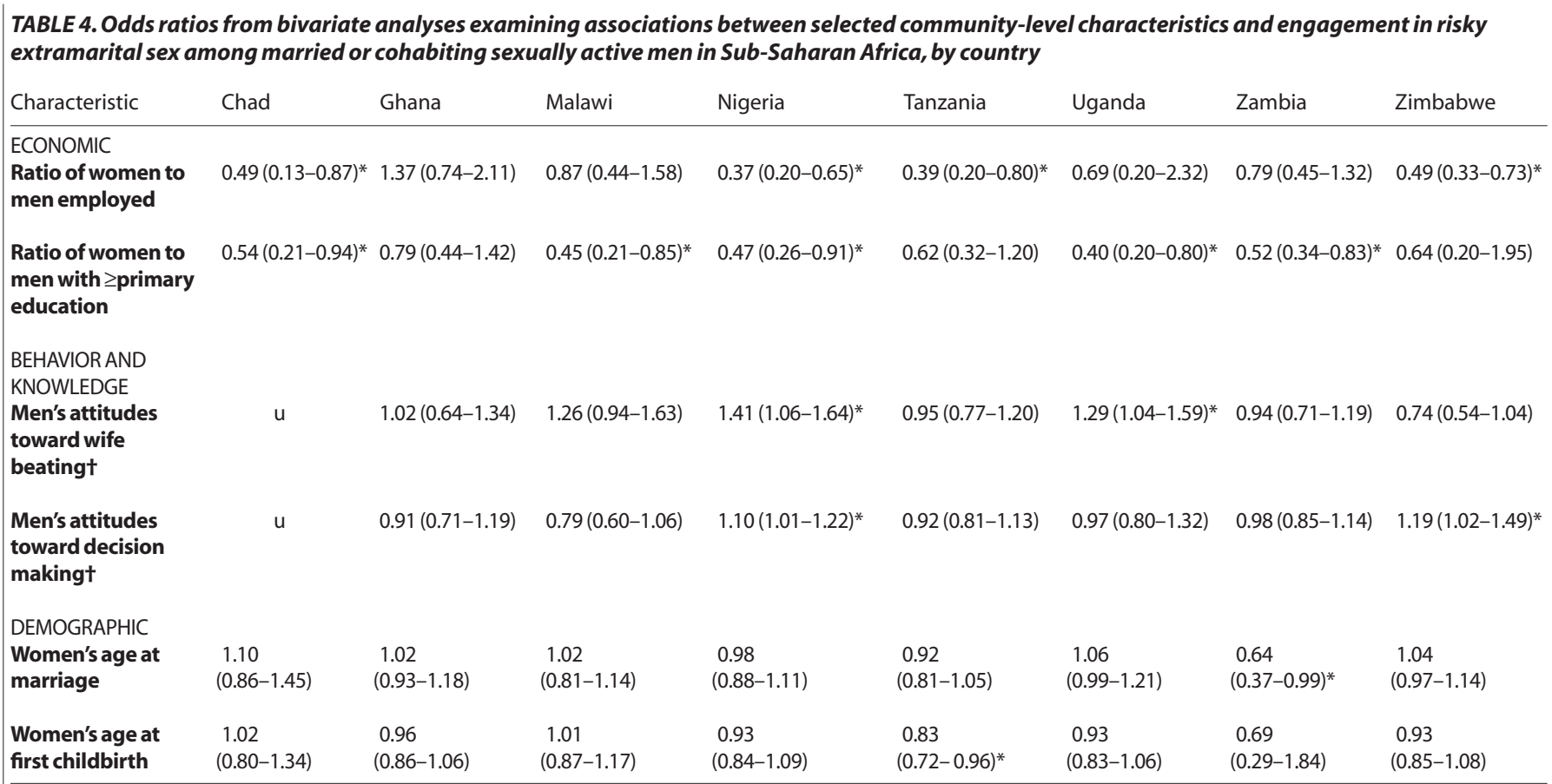

*p<.05. . On a scale of 0 to 5 , with higher values reflecting more favorable attitudes toward wife-beating or greater domination of decision making. Note: $u=u n a v a i l a b l e$.

to men who had achieved at least a primary education was associated with reduced odds of men's reporting risky sex in Chad, Malawi, Nigeria, Uganda and Zambia (0.4-0.6 per 0.10 increase in the ratio). Higher community scores on the index measuring attitudes toward wife-beating were associated with men's extramarital sexual risk-taking in Nigeria and Uganda (1.5 and 1.3, respectively, per one-unit change in score). Residence in a community with a higher mean score among men on the decision-making index was associated with elevated levels of male sexual risk-taking in Nigeria and Zimbabwe (1.1 and 1.3, respectively, per oneunit change in score). For men in Zambia, living in a community with a higher mean age at first marriage for women was associated with significantly lower odds of having had risky extramarital sex (0.8 per year). In Tanzania, residence in a community with a higher mean age at first delivery among women was associated with significantly lower odds of men's reporting sexual risk-taking ( 0.8 per year). The community-level random intercept term was significant in all eight countries; thus, after controlling for the other variables in the models, the odds of reporting risky extramarital sex varied significantly across communities, and at the community level the models do not fully explain the factors that shape men's sexual risk-taking.

\section{DISCUSSION}

At the individual and household levels, few consistent results emerged across countries. The finding that men who had had sex for the first time at age 21 or older were less likely to report risky sex than were those who had been 15 or younger at first sex is interesting and worthy of further investigation. Men who delay first sex, possibly until after marriage, may be less prone than their peers to taking sex- ual risks in general. Interestingly, in four countries, men in cohabiting unions were less likely than married men to engage in sexual risk-taking outside of the union. In the absence of a legal or civil agreement between partners, women retain more ability to leave their partners; thus, men in cohabiting unions may tend to refrain from having sex outside the relationship because they do not want to risk losing their partner. Men who had achieved only a primary education and those who worked for pay had increased odds of risky extramarital sex in some countries; these results may reflect greater access to social capital and greater social freedom among such men than among men who are not educated or employed, and thus greater opportunities and resources to engage in casual sex.

Several community-level factors were associated with lower odds of men's extramarital sexual risk-taking. In communities characterized by greater gender equity (i.e., more equal ratios of men and women with access to education and employment), levels of extramarital sexual risktaking were generally lower. In contexts where opportunities to accrue social capital are less biased toward men, women may be less economically dependent on men and have more negotiating power in relationships-and thus be more able to negotiate for monogamy or condom use. Communities where the ratio of men to women who received an education is more equal may also be areas where higher value is placed on providing opportunities for women to accrue social capital. Therefore, while the resources that come with education and employment may reduce sexual risk-taking among men, it may also be that communities that allow women to obtain these resources are also generally supportive of women's rights.

Living in a community where women marry or give 


\begin{tabular}{|c|c|c|c|c|c|c|c|c|}
\hline Characteristic & Chad & Ghana & Malawi & Nigeria & Tanzania & Uganda & Zambia & Zimbabwe \\
\hline \multicolumn{9}{|l|}{ INDIVIDUAL } \\
\hline \multicolumn{9}{|l|}{ Age } \\
\hline $15-24$ (ref) & 1.00 & 1.00 & 1.00 & 1.00 & 1.00 & 1.00 & 1.00 & 1.00 \\
\hline $25-29$ & $0.98(0.61-1.58)$ & $0.74(0.45-1.19)$ & $0.95(0.66-1.35)$ & $2.11(1.33-3.33)^{*}$ & $0.97(0.86-1.57)$ & $1.30(0.87-1.95)$ & $0.96(0.56-1.65)$ & $1.40(1.06-1.84)^{*}$ \\
\hline $30-34$ & $0.57(0.32-1.01)$ & $0.72(0.45-1.15)$ & $1.08(0.73-1.61)$ & $1.83(1.08-3.09)^{*}$ & $0.92(0.60-1.41)$ & $1.31(0.84-2.03)$ & $0.81(0.48-1.37)$ & $1.23(0.89-1.69)$ \\
\hline $35-39$ & $0.97(0.54-1.73)$ & $0.71(0.36-1.17)$ & $1.01(0.65-1.57)$ & $2.00(1.11-3.60)^{*}$ & $0.89(0.56-1.41)$ & $1.39(0.84-2.08)$ & $0.81(0.54-1.39)$ & $0.92(0.64-1.31)$ \\
\hline$\geq 40$ & $0.55(0.32-0.95)^{*}$ & $0.87(0.45-1.18)$ & $1.14(0.78-1.69)$ & $2.69(1.57-4.67)^{*}$ & $0.79(0.51-1.22)$ & $0.98(0.63-1.51)$ & $0.76(0.45-1.89)$ & $0.78(0.55-1.09)$ \\
\hline \multicolumn{9}{|l|}{ Union type } \\
\hline Married (ref) & 1.00 & 1.00 & 1.00 & 1.00 & 1.00 & 1.00 & 1.00 & 1.00 \\
\hline Cohabiting & $0.45(0.29-0.70)^{*}$ & $0.49(0.31-0.78)^{*}$ & $0.59(0.38-0.92)^{*}$ & $0.67(0.37-1.21)$ & $1.39(0.92-2.10)$ & $1.60(1.07-2.39)^{*}$ & $1.41(0.28-1.69)$ & $0.12(0.07-0.19)^{*}$ \\
\hline \multicolumn{9}{|l|}{ Residence } \\
\hline Rural & $0.60(0.36-0.99)^{*}$ & $1.03(0.90-1.18)$ & $0.82(0.61-1.09)$ & $1.10(0.85-1.41)$ & $1.17(0.87-1.57)$ & $0.89(0.64-1.24)$ & $1.51(1.10-2.08)^{*}$ & $0.82(0.63-1.06)$ \\
\hline Urban (ref) & 1.00 & 1.00 & 1.00 & 1.00 & 1.00 & 1.00 & 1.00 & 1.00 \\
\hline \multicolumn{9}{|l|}{ Age at first sex } \\
\hline$\leq 15$ (ref) & 1.00 & 1.00 & 1.00 & 1.00 & 1.00 & 1.00 & 1.00 & 1.00 \\
\hline $16-20$ & $1.07(0.79-1.43)$ & $1.09(0.82-1.43)$ & $0.96(0.79-1.17)$ & $0.89(0.66-1.20)$ & $0.83(0.67-1.03)$ & $1.03(0.83-1.27)$ & $0.85(0.67-1.08)$ & $0.98(0.73-1.09)$ \\
\hline$\geq 21$ & $0.53(0.36-0.78)^{*}$ & $0.71(0.52-0.99)^{*}$ & $0.57(0.43-0.75)^{*}$ & $0.41(0.29-0.58)^{*}$ & $0.38(0.28-0.51)^{*}$ & $0.66(0.47-0.95)^{*}$ & $0.58(0.39-0.85)^{*}$ & $0.47(0.37-0.61)^{*}$ \\
\hline \multicolumn{9}{|l|}{ Education } \\
\hline None (ref) & 1.00 & 1.00 & 1.00 & 1.00 & 1.00 & 1.00 & 1.00 & 1.00 \\
\hline Primary & $0.82(0.55-1.21)$ & $1.13(0.80-1.60)$ & $1.37(1.02-1.89)^{*}$ & $1.04(0.69-1.56)$ & $1.45(1.03-2.07)^{*}$ & $1.84(1.14-2.98)^{*}$ & $1.65(0.88-3.12)$ & $0.68(0.49-1.52)$ \\
\hline Secondary & $0.74(0.48-1.16)$ & $1.28(0.91-1.79)$ & 1.07 (0.73-1.57) & $1.12(0.71-1.75)$ & $1.14(0.71-1.85)$ & $1.23(0.72-2.09)$ & $1.28(0.65-2.49)$ & $0.85(0.48-1.52)$ \\
\hline >secondary & $0.72(0.40-1.32)$ & $1.22(0.75-1.99)$ & $0.93(0.45-1.91)$ & $0.99(0.60-1.64)$ & $1.24(0.65-2.36)$ & $1.43(0.77-2.67)$ & $0.57(0.23-1.41)$ & $0.69(0.35-1.29)$ \\
\hline \multicolumn{9}{|l|}{ Employed } \\
\hline Yes & $0.90(0.62-1.29)$ & $1.42(1.02-1.96)^{*}$ & $1.27(1.02-1.61)^{*}$ & $0.97(0.70-1.34)$ & $1.68(1.17-2.38)^{*}$ & $2.08(1.11-3.89)^{*}$ & $1.87(1.35-2.59)^{*}$ & $1.32(1.11-1.58)^{*}$ \\
\hline No (ref) & 1.00 & 1.00 & 1.00 & 1.00 & 1.00 & 1.00 & 1.00 & 1.00 \\
\hline \multicolumn{9}{|l|}{ HOUSEHOLD } \\
\hline \multicolumn{9}{|l|}{ Wealth quintile } \\
\hline Lowest (ref) & 1.00 & 1.00 & 1.00 & 1.00 & 1.00 & 1.00 & na & 1.00 \\
\hline Second lowest & $0.91(0.51-1.60)$ & $1.08(0.79-1.47)$ & $1.14(0.85-1.54)$ & $1.06(0.73-1.57)$ & $0.98(0.73-1.30)$ & $1.02(0.75-1.39)$ & na & $0.95(0.76-1.20)$ \\
\hline Middle & $1.11(0.63-1.94)$ & $1.29(0.95-1.80)$ & $1.08(0.81-1.45)$ & $1.12(0.71-1.75)$ & $1.05(0.78-1.42)$ & $1.02(0.73-1.42)$ & na & $0.98(0.77-1.25)$ \\
\hline Second highest & $0.90(0.50-1.61)$ & $1.10(0.73-1.65)$ & $1.21(0.95-1.60)$ & $0.99(0.60-1.64)$ & $0.95(0.70-1.29)$ & $1.15(0.82-1.61)$ & na & $1.01(0.76-1.33)$ \\
\hline Highest & $1.29(0.66-2.53)$ & $1.23(0.78-1.95)$ & $1.33(0.95-1.88)$ & $0.57(0.36-0.91)^{*}$ & $1.45(0.97-2.16)$ & $1.54(1.04-2.07)^{*}$ & na & $0.92(0.64-1.32)$ \\
\hline \multicolumn{9}{|l|}{ COMMUNITY } \\
\hline $\begin{array}{l}\text { Ratio of women to } \\
\text { men employed }\end{array}$ & $0.52(0.26-0.99)^{*}$ & $1.45(0.75-2.78)$ & $0.87(0.45-1.67)$ & $0.42(0.21-0.69)^{*}$ & $0.42(0.21-0.81)^{*}$ & $0.69(0.19-2.49)$ & $0.81(0.47-1.39)$ & $0.50(0.34-0.74)^{*}$ \\
\hline $\begin{array}{l}\text { Ratio of women to } \\
\text { men with } \geq \text { primary } \\
\text { education }\end{array}$ & $0.58(0.27-0.98)^{*}$ & $0.79(0.44-1.42)$ & $0.48(0.26-0.87)^{*}$ & $0.49(0.26-0.91)^{*}$ & $0.64(0.34-1.18)$ & $0.42(0.21-0.81)^{*}$ & $0.53(0.33-0.85)^{*}$ & $0.64(0.20-1.95)$ \\
\hline $\begin{array}{l}\text { Men's attitudes } \\
\text { toward wife } \\
\text { beating }\end{array}$ & $\mathrm{u}$ & $1.06(0.79-1.42)$ & $1.26(0.95-1.66)$ & $1.49(1.08-1.72)^{*}$ & $0.97(0.79-1.18)$ & $1.32(1.05-1.66)^{*}$ & $0.95(0.75-1.21)$ & $0.90(0.68-1.19)$ \\
\hline $\begin{array}{l}\text { Men's attitudes } \\
\text { toward decision } \\
\text { making }\end{array}$ & $\mathrm{u}$ & $0.94(0.79-1.13)$ & $0.83(0.65-1.07)$ & $1.11(1.02-1.23)^{*}$ & $0.96(0.84-1.10)$ & $0.97(0.84-1.34)$ & $0.98(0.85-1.14)$ & $1.28(1.05-1.55)^{*}$ \\
\hline $\begin{array}{l}\text { Women's age at } \\
\text { marriage }\end{array}$ & $1.14(0.94-1.37)$ & $1.03(0.94-1.11)$ & $1.02(0.88-1.15)$ & $0.99(0.89-1.09)$ & $0.93(0.84-1.03)$ & $1.07(0.95-1.20)$ & $0.79(0.36-0.98)^{*}$ & $1.06(0.99-1.15)$ \\
\hline $\begin{array}{l}\text { Women's age at } \\
\text { first childbirth }\end{array}$ & $1.05(0.89-1.25)$ & $0.98(0.89-1.07)$ & $1.01(0.88-1.16)$ & $0.94(0.85-1.05)$ & $0.83(0.74-0.93)^{*}$ & $0.94(0.83-1.07)$ & $0.76(0.31-1.91)$ & $0.95(0.87-1.04)$ \\
\hline $\begin{array}{l}\text { Community-level } \\
\text { random intercept }\end{array}$ & $0.683(0.071)$ & $0.217(0.053)$ & $0.274(0.98)$ & $0.357(0.84)$ & $0.484(0.142)$ & $0.154(0.045)$ & $0.382(0.149)$ & $0.194(0.081)$ \\
\hline
\end{tabular}

birth at an older age was also associated with reduced extramarital sexual risk-taking among men in some instances. Again, this finding may reflect attitudes toward women in these communities. When women marry later and delay their first birth, they are better able to take advantage of opportunities for economic and social ad- vancement. However, this requires a community that values and supports women's contributions outside of the home, and views women as equal to men. Communities with higher levels of extramarital sexual risk-taking had more conservative attitudes toward wife-beating and decision making, reinforcing the argument that extramarital 
sexual activity is more prevalent in communities characterized by less gender equity.

These factors, however, do not fully explain the role of the community in shaping extramarital sexual activity. Significant community-level variation remained in all countries, demonstrating the need for further investigation and data collection efforts to identify other dimensions of community environments that may influence the sexual behavior of married men.

This study had several limitations. First, the analysis relied on self-reported data on sexual behavior, and men may overreport sexual activity. ${ }^{42,43}$ The DHS data, however, remain the only routinely collected and comparable information on men's sexual behavior in Africa, and the findings gained in the present analysis outweigh this potential bias. Second, the community-level variables used in the analysis were derived from individual-level data, because comparable community-level data were unavailable. Therefore, information on health facilities and ongoing educational and behavioral change activities in the community are missing from the analysis, an absence that is likely reflected in the significant random effects terms.

The results reported here demonstrate the range of ways in which the community environment can influence sexual risk-taking among married men, and suggest that such risk-taking is influenced by differential access to resources for men and women. However, communities were conceptualized as small geographic units (primary sampling units) in this analysis, and this approach may not accurately capture what individuals consider their community. Future analyses of this sort should focus on other types of communities, such as ethnic or religious groups, and examine how shared characteristics of those groups influence the risk-taking of their members.

\section{Conclusion}

As heterosexual adults continue to be the most at-risk group for HIV infection in many parts of Sub-Saharan Africa, it is imperative that effective behavioral change interventions be developed. An understanding of the role of community characteristics in sexual risk-taking is an integral step in this process. The sexual risk-taking of married men contributes to the heterosexual transmission of HIV, and the results described in this study suggest that culturally and economically created gender inequities play an important role. The results highlight the need for HIV intervention efforts to tackle deeply rooted ideals surrounding gender expectations and behaviors. Efforts to stem the heterosexual transmission of HIV need to take a holistic view of gender. While a focus on the inequities between women and men and on improving women's position relative to men should be maintained, such efforts also need to recognize the many cultural influences on men's identity formation and sexual behavior, and incorporate these into intervention efforts. Programs that discuss and challenge the factors behind men's sexual behavior may provide an opportunity for communities to initiate behavioral change.

\section{REFERENCES}

1. Smith DJ, Modern marriage, men's extramarital sex, and HIV risk in southeastern Nigeria, American Journal of Public Health, 2007, 97(6): 997-1005.

2. Dunkle K et al., New heterosexually transmitted HIV infections in married or cohabiting couples in urban Zambia and Rwanda: an analy sis of survey and clinical data, Lancet, 2008, 371(9631):2183-2191.

3. Pulerwitz J, Izazola-Licea JA and Gortmaker SL, Extrarelational sex among Mexican men and their partners' risk of HIV and other sexually transmitted diseases, American Journal of Public Health, 2001, 91(10): 1650-1652.

4. Amaro H, Love, sex, and power: considering women's realities in HIV prevention, American Psychologist, 1995, 50(6):437-447.

5. Smith DJ, 'Man no be wood': gender and extramarital sex in contemporary southeastern Nigeria, Ahfad Journal, 2002, 19(2):4-23.

6. Cornwall A, Spending power: love, money, and the reconfiguration of gender relations in Ada-Odo, southwestern Nigeria, American Ethnologist, 2002, 29(4):963-980

7. Caldwell JC, Caldwell P and Quiggin P, The social context of AIDS in Sub-Saharan Africa, Population and Development Review, 1989, 15(2):185-234

8. Hunter M, Cultural politics and masculinities: multiple-partners in historical perspective in KwaZulu-Natal, Culture, Health and Sexuality, 2005, 7(4):389-403.

9. Morris $\mathrm{M}$ and Kretzschmar M, Concurrent partnerships and the spread of HIV, AIDS, 1997, 11(5):641-648

10. Lagarde E et al., Concurrent sexual partnerships and HIV prevalence in five urban communities of Sub-Saharan Africa, AIDS, 2001, 15(7):877-884

11. Baeten JM et al., Female-to-male infectivity of HIV-1 among circumcised and uncircumcised Kenyan men, Journal of Infectious Diseases, 2005, 191(4):546-553.

12. Harrison A, Xaba N and Kunene P, Understanding safe sex: gender narratives of HIV and pregnancy prevention by rural South African school-going youth, Reproductive Health Matters, 2001, 9(17):63-71.

13. Mataure P et al., Men and HIV in Swaziland, Johannesburg, South Africa: Panos, Southern Africa AIDS Information Dissemination Service and Joint United Nations Programme on HIV/AIDS (UNAIDS), 2000.

14. MacPhail $\mathrm{C}$ and Campbell C, 'I think condoms are good but, aai, I hate those things': condom use among adolescents and young people in a Southern African township, Social Science \& Medicine, 2001, 52(11):1613-1627.

15. Longfield K, Cramer R and Sachingongu N, Misconceptions, folk beliefs, and denial: young men's risk for STIs and HIV/AIDS in Zambia 2003, PSI Research Division Working Paper, Washington, DC: Population Service International, 2003, No. 53.

16. Barker $G$ and Ricardo C, Young men and the construction of masculinity in Sub-Saharan Africa: implications for HIV/AIDS, conflict and violence, Social Development Papers: Conflict Prevention and Reconstruction, Washington, DC: World Bank, 2005, No. 26.

17. Pulerwitz J, Barker G and Segundo M, Promoting healthy relationships and HIV/STI prevention for young men: positive findings from an intervention study in Brazil, Horizons Research Update, Washington, DC: Population Council, 2004

18. Kimuna SR and Djamba YK, Wealth and extramarital sex among men in Zambia, International Family Planning Perspectives, 2005, 31(2) $83-89$.

19. Mitsunaga TM et al., Extramarital sex among Nigerian men: polyg yny and other risk factors, Journal of Acquired Immune Deficiency Syndromes, 2005, 39(4):478-488.

20. Orubuloye IO, Caldwell JC and Caldwell P, Sexual networking in the Ekiti district of Nigeria, Studies in Family Planning, 1991, 22(2): 61-73.

21. Isiugo-Abanihe UC, Extramarital relations and perceptions of HIV/AIDS in Nigeria, Health Transition Review, 1994, 4(2):111-125. 
22. Rivers K and Aggleton P, Adolescent Sexuality, Gender, and the HIV Epidemic, New York: HIV and Development Programme, United Nations Development Programme, 1999.

23. Campbell C, Migrancy, masculine identities and AIDS: the psychosocial context of HIV transmission on the South African gold mines, Social Science \& Medicine, 1997, 45(2):273-281.

24. Wood K and Jewkes R, Dangerous love: reflections on violence among Xhosa township youth, in: Morrell R, ed., Changing Men in Southern Africa, Pietermaritzburg, South Africa: University of Natal Press, 2001.

25. Hunter M, The materiality of everyday sex: thinking beyond 'prostitution,' African Studies, 2002, 61(1):99-120.

26. Leach F, Learning to be violent: the role of the school in developing adolescent gendered behaviour, Compare, 2003, 33(3):385-400.

27. Abrahams $N$ et al., Sexual violence against intimate partners in Cape Town: prevalence and risk factors reported by men, Bulletin of the World Health Organization, 2004, 82(5):330-337.

28. Marsiglio W, Adolescent male sexuality and heterosexual masculinity: a conceptual model and review, Journal of Adolescent Research, 1988, 3(3-4):285-303.

29. World Health Organization (WHO) and UNAIDS, The Health and Development of African Male Adolescents and Young Men, Geneva: WHO, 2001.

30. Varga CA, The forgotten fifty per cent: a review of sexual and reproductive health research and programs focused on boys and young men in Sub-Saharan Africa, African Journal of Reproductive Health, 2001, 5(3):175-195.

31. Barker G, Gender equitable boys in a gender inequitable world: reflections from qualitative research and programme development in Rio de Janeiro, Sexual and Relationship Therapy, 2000, 15(3):263-282.

32. Cleland JG, Ali MM and Capo-Chichi V, Post-partum sexual abstinence in West Africa: implications for AIDS-control and family planning programmes, AIDS, 1999, 13(1):125-131.

33. Ali MM and Cleland JG, The link between postnatal abstinence and extramarital sex in Côte d'Ivoire, Studies in Family Planning, 2001, 32(3):214-219.

34. Chirwa W, Aliens and AIDS in southern Africa: the Malawi-South Africa debate, African Affairs, 1998, 97(386):53-79.

35. Kaler A, Many divorces and many spinsters: marriage as an invented tradition in southern Malawi, 1946-1969, Journal of Family History, 2001, 26(4):529-556.

36. Setel PW, Lewis M and Lyons M, eds., Histories of Sexually Transmitted Diseases and HIV/AIDS in Sub-Saharan Africa, Westport, CT, USA: Greenwood Press, 1999.

37. Tawfik L and Watkins SC, Sex in Geneva, sex in Lilongwe, and sex in Balaka, Social Science \& Medicine, 2007, 64(5):1090-1101.

38. Silberschmidt M, Disempowerment of men in rural and urban East Africa: implications for male identity and sexual behavior, World Development, 2001, 29(4):657-671.

39. Cornwall AA, To be a man is more than a day's work: shifting ideals of masculinity in Ado-Odo, southwestern Nigeria, in: Lindsay LA and Miescher SF, eds., Men and Masculinities in Modern Africa, Portsmouth, NH, USA: Heinemann, 2003.

40. Agadjanian V, Men doing "women's work": masculinity and gender relations among street vendors in Maputo, Mozambique, Journal of Men's Studies, 2002, 10(3):329-342.

41. Goldstein H, Multilevel Statistical Models, London: Edward Arnold, 1995.

42. Glynn JR et al., Why do young women have a much higher prevalence of HIV than young men? A study in Kisumu, Kenya and Ndola, Zambia, AIDS, 2001, 15(Suppl. 4):S51-S60.

43. Zaba B et al., Trends in age at first sex: an application of survival analysis techniques to survey data from Africa, paper presented at the annual meeting of the Population Association of America, Atlanta, GA, USA, May 9-11, 2002.

\section{RESUMEN}

Contexto: En muchas partes de África, es más probable que las mujeres se infecten con el VIH por tener relaciones sexuales sin protección con sus esposos, quienes pueden haberse contagiado con el virus a través de relaciones extramaritales. Sin embargo, no hay una plena comprensión de las formas en las que los aspectos de los entornos comunitarios-especialmente aquellos relacionados con la equidad de género-dan forma a la toma de riesgos sexuales extramaritales de los hombres.

Métodos: Datos de las Encuestas Demográficas y de Salud de ocho países africanos (Chad, Ghana, Malaui, Nigeria, Tanzania, Uganda, Zambia y Zimbabue) se utilizaron para examinar las asociaciones entre el hecho de que los hombres casados participen en relaciones extramaritales riesgosas (i.e., que hayan tenido relaciones sexuales sin protección tanto con parejas casuales como su propia esposa) y los indicadores de equidad de género y otras características de la comunidad. Se crearon modelos logísticos multinivel separados que incorporaron medidas a nivel individual, familiar y comunitario para cada país.

Resultados: En cinco países, los hombres que vivían en comunidades en que fue similar la razón mujer-hombre en cuanto al tener al menos educación primaria, tuvieron menor probabilidad de reportar actividad sexual extramarital (razones de momios, 0.4-0.6). Una relación similar se encontró en cuatro países con la razón igual mujer-hombre en cuanto al empleo (0.4-0.5). En tres países, los hombres que vivían en comunidades con actitudes más conservadoras respecto a golpear a la esposa o la toma de decisiones por parte del hombre, tuvieron altas probabilidades de toma de riesgos sexuales extramaritales (1.1-1.5).

Conclusiones: Si bien los programas de prevención del VIH deben enfocarse en la reducción de las inequidades de género, también deben reconocer los factores culturales conservadores que influyen en la formación de las identidades masculinas de los hombres y que, a su vez, afectan su comportamiento sexual.

\section{RÉSUMÉ}

Contexte: Dans de nombreuses régions d'Afrique, les femmes courent le plus grand risque d'infection à VIH en ayant des rapports sexuels non protégés avec leur mari, qui peut lui-même avoir contracté le virus lors de rapports sexuels extraconjugaux. La manière dont certains aspects du milieu communautaire-en particulier ceux ayant trait à l'égalité de genrefaçonnent la prise de risques sexuels extraconjugaux chez les hommes n'est cependant pas bien comprise.

Méthodes: Les données des Enquêtes démographiques et de santé (EDS) de huit pays d'Afrique (Tchad, Ghana, Malawi, Nigéria, Tanzanie, Ouganda, Zambie et Zimbabwe) servent à l'examen des associations entre l'engagement des hommes mariés dans des relations sexuelles extraconjugales à risques (par des rapports non protégés avec des partenaires de passage aussi bien qu'avec leur épouse, notamment) et les indicateurs d'égalité de genre et autres caractéristiques communautaires. Des modèles logistiques multiniveaux distincts incorporant des mesures de niveau individuel, de ménage et de communauté ont été créés pour chaque pays. 
Résultats: Dans cinq pays, les hommes vivant dans des communautés présentant des rapports plus égalitaires de femmes/hommes instruits pour le moins au niveau primaire se révèlent moins susceptibles de déclarer une activité sexuelle extraconjugale risquée (rapports de probabilités, 0,4-0,6). Une relation similaire est observée dans quatre pays concernant le rapport entre les femmes et les hommes employés $(0,4-0,5)$. Dans trois pays, les hommes vivant dans des communautés présentant des attitudes plus conservatrices à l'égard de la violence conjugale ou du privilège de décision masculine se caractérisent par une probabilité élevée de prise de risque sexuel extraconjugal (1,1-1,5).

Conclusions: S'il importe que les programmes de prévention du VIH se concentrent sur la réduction des inégalités de genre, il faut aussi qu'ils reconnaissent les facteurs culturels conservateurs qui influencent la formation de l'identité masculine des hommes et qui affectent par conséquent leur comportement sexuel.

Author contact:rbsteph@sph.emory.edu 